Popović, T., Matijašević, S., Raičević, D., Mijović, S. (2020): Influence of vine loads with fertile buds on grape yield and quality of variety Žižak in Podgorica vineyard area. Agriculture and Forestry, 66 (3): 241-250.

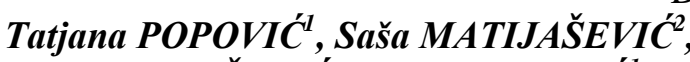 \\ Danijela RAIČEVIĆ, Slavko MIJOVIĆl
}

DOI: 10.17707/AgricultForest.66.3.20

\title{
INFLUENCE OF VINE LOADS WITH FERTILE BUDS ON GRAPE YIELD AND QUALITY OF VARIETY ŽIŽAK IN PODGORICA VINEYARD AREA
}

\section{SUMMARY}

Results of a two - year study of the influence of different vine loads with fertile buds on elements of grape yield and quality of Žižak grape variety are presented in this paper. The research was conducted in the Podgorica sub region, at the Lješkopolje site. Four different vine loads with fertile buds were applied: 14 buds, 18 buds, 20 and 24 buds per vine. The results of this research show that the applied loads significantly influence the examined parameters of the autochthonous variety Žižak. The highest percentage of developed and fertile shoots, as well as the average number of flowers per bud, had a variant with load of 14 buds. The relative coefficient of yielding in all examined load variants had mean values. In terms of the number of flowers per fertile shoot in the two-year average, variants with a load of 18 and 14 buds (1.44 and 1.39) stood out. The highest yield of grapes in the two-year average had the variant with a load of 24 buds - $3.60 \mathrm{~kg} / \mathrm{vine}$, while the highest bunch weight had the variant V1-185 $\mathrm{g}$. The quality of grapes also varied significantly under the influence of the vine load with fertile buds. The highest sugar content in must had variant with a load of 18 buds $(22.32 \%)$, while the highest acid content $(6.27 \mathrm{~g} / \mathrm{l})$ was recorded in the variant with 24 buds per vine.

Keywords: Žižak, load, fertility, yield, bunch weight, grape quality

\section{INTRODUCTION}

Pruning is an ampelotechnical measure that should enable the achievement of maximum yields of grapes, without reflecting on the weakening of the vegetative power of the vine and deterioration of quality of grapes (Cindrić et al., 2000). This ampelotechnical measure seeks to ensure balance between vegetative strength and condition of vine and the quality of grape yield, in a manner that does not jeopardize productive capacity of the vine during decades of vineyard exploitation (Mijatović et al., 2018). Pruning maintains the cultivation form of the

\footnotetext{
${ }^{1}$ Tatjana Popović (corresponding author: tatjanapopovic@t-com.me), Danijela Raičević, Slavko Mijović, Biotechnical faculty Podgorica, MONTENEGRO.

${ }^{2}$ Saša Matijašević, Faculty of Agriculture Belgrade, SERBIA .

Notes: The authors declare that they have no conflicts of interest. Authorship Form signed online. 
vine, regulates the vegetative and fertile potential, and indirectly affects the quantity and quality of grape yield (Mirošević et al., 2008).

Proper loading of vines with fertile buds is achieved on the basis of knowledge on the vegetative potential of vines, agrotechnical growing conditions and the quality of grape yield that is to be achieved (Vujović, 2013). The optimal load of vines with fertile buds for each variety must be in accordance with its biological characteristics. Leaf size and leaf area, movement and yield of buds, shoot growth, yield, grape quality, etc. largely depend on the optimal load of vines with fertile buds (Pejović, 1982). Therefore, in each vineyard region, it is necessary to establish the optimal load of vines with fertile buds for all varieties and cultivation forms of vines, in accordance with the technology of grape production, which will give the most favourable production results. Any subsequent engagement of labour in order to regulate and correct the yield during the growing season additionally burdens production.

Viticulture has a long tradition in Montenegro and indigenous grape varieties Vranac, Kratošija, Krstač and Žižak play a very important role in the viticulture and winemaking sector (Maraš et al., 2012). In modern viticultural production, the variety is a very important factor of success, because its unique genotype directly affects the yield of grapes, sugar content and total acids in the must as basis of economic and technological characteristics (Sefo et al., 2020).

Žižak variety is an autochthonous Montenegrin variety. Burić (1995) states that quality white refreshing wines are made from its grapes and in some years also wines of top quality. Except in the vineyards in Podgorica, individual vines of this indigenous variety can still be found in Crmnica and in Montenegrin coast (Savić, 2003). Maraš et al. (2015) state that grapes of Žižak variety are used in certain areas of Boka for the production of Prošek dessert wine.The aim of this research was to examine the influence of different load of vines with fertile buds on some biological and technological characteristics of autochthonous white wine variety Žižak. Based on the results, the optimal load of vines with buds that will enable the achievement of high quality grapes and wine is to be determined.

\section{MATERIAL AND METHODS}

The research of the influence of different vine loads with fertile buds on yield and quality of grapes of the Žižak variety was performed during 2015 and 2016. The study was performed at the experimental filed of the Biotechnical Faculty in Podgorica. The experimental vineyard was planted in 2005 with a planting distance of $2.5 \mathrm{~m}$ between rows and $1 \mathrm{~m}$ within the row. The training system of the vine is a two-arm horizontal cordon with a tree height of about 80 $\mathrm{cm}$. Short and mixed pruning was applied. The experiment includes the following variants: V1 - 14 buds (2 long spurs with 5 buds each and 2 spurs with 2 buds each); V2 - 18 buds ( 2 canes with 7 buds each and 2 spurs with 2 buds each); V3 - 20 buds ( 2 canes with 8 buds each and 2 spurs with 2 buds each); V4 (control) 24 buds ( 2 canes with 10 buds each and 2 spurs with 2 buds each). 
The research was performed on 120 vines, that is, in three replications with 10 vines for each variant. During the two-year study, the percentage of emerged and fertile shoots, potential, relative and absolute fertility rate, grape yield $(\mathrm{kg} / \mathrm{vine})$, bunch weight $(\mathrm{g})$, and sugar $(\%)$ and acid $(\mathrm{g} / \mathrm{l})$ content in must were examined.

-The percentage of total developed shoots per vine was determined from the ratio of the number of developed shoots and the number of buds left with pruning,

-The percentage of fertile shoots per vine was determined from the ratio of the number of fertile and the number of total developed shoots,

-The average number of flowers per bud (potential yield rate) was obtained from the ratio of the total number of flowers and the number of buds left with pruning,

-The average number of flowers per shoot was determined from the ratio of the total number of flowers and the number of developed shoots (relative fertility rate),

-The average number of flowers per fertile shoot (fertility rate) was obtained from the ratio of the total number of flowers and the number of fertile shoots,

-The yield of grapes was obtained by measuring harvested grapes, and the bunch weight was determined from the ratio of the yield from ten vines and the number of bunches.

-The content of sugar in the most was determined hydrometrically (Oechsle hydrometer), and the content of total acids in the must by neutralization of all acids and their salts with $\mathrm{n} / 10 \mathrm{NaOH}$ solution using the bromothymol blue indicator.

Data from the meteorological station in Podgorica were used in the analysis of climatic conditions in Lješkopolje. Data were processed by analysis of variance for a completely randomized block design. Significance of differences was determined using the LSD test.

\section{RESULTS AND DISCUSSION}

\section{Climate conditions}

Meteorological conditions prevailing in production regions have high influence on quantity and quality of grape yield (Mirošević and Karoglan Kontić, 2008). Of all the climatic factors, the air temperature has the most dominant influence on the growth of vine, its fertility, as well as quantity and quality of grape yield. Based on the data from Table 1, the average annual air temperature in the first year of research was $17.2^{\circ} \mathrm{C}$, which is $0.6^{\circ} \mathrm{C}$ higher than in 2016. Mean temperature in the vegetation period was also higher in the first year of research and was $23.2{ }^{\circ} \mathrm{C}$. In the studied period, the highest vegetation sum of temperature was measured in $2015\left(4973.1^{\circ} \mathrm{C}\right)$ 
Table 1. Average monthly, annual and vegetative air temperature $\left({ }^{\circ} \mathrm{C}\right)$

\begin{tabular}{|c|c|c|c|c|c|c|c|c|c|c|c|c|c|c|c|}
\hline \multirow[b]{2}{*}{ Year } & \multicolumn{12}{|c|}{ Months } & \multirow[b]{2}{*}{ 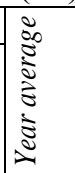 } & \multirow[b]{2}{*}{ 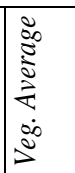 } & \multirow[b]{2}{*}{ 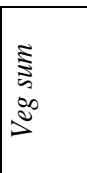 } \\
\hline & I & II & III & IV & $\mathrm{V}$ & VI & VII & VIII & IX & $\mathrm{X}$ & XI & XII & & & \\
\hline 2015. & 6.4 & 7.7 & 11.0 & 14.7 & 21.1 & 25.6 & 31.0 & 29.0 & 24.1 & 17.0 & 11.9 & 6.6 & \begin{tabular}{|l}
17.2 \\
\end{tabular} & 23.2 & 4973.1 \\
\hline 2016. & 6.5 & 10.8 & 11.5 & 17.2 & 18.6 & 24.7 & 28.3 & 27.6 & 22.1 & 15.9 & 10.4 & 5.3 & 16.6 & 22.0 & $\overline{4723.0}$ \\
\hline Average & 6.4 & 9.2 & 11.2 & 15.9 & 19.8 & 25.1 & 29.6 & 28.3 & 23.1 & 16.4 & 11.1 & 5.9 & 16.9 & 22.6 & 4848.0 \\
\hline
\end{tabular}

The results given in Table 2 show that in Podgorica vineyard area, the average annual rainfall for 2015 was $1176.0 \mathrm{~mm}$, while in 2016 it was significantly higher and amounted $1993.7 \mathrm{~mm}$. Observing the sum of precipitation in the vegetation period, only $438.01 / \mathrm{m}^{2}$ of rain fell in 2015 , which is significantly less than in 2016 , when $899.51 / \mathrm{m}^{2}$ of water sediments were measured during the vegetation period.

Table 2. Average monthly, annual and vegetative rainfall $(\mathrm{mm})$

\begin{tabular}{|c|c|c|c|c|c|c|c|c|c|c|c|c|c|c|}
\hline \multirow[b]{2}{*}{ Year } & \multicolumn{12}{|c|}{ Months } & \multirow{2}{*}{ 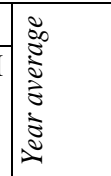 } & \multirow[b]{2}{*}{$\begin{array}{l}\text { 意 } \\
\infty \\
D^{\circ}\end{array}$} \\
\hline & I & II & III & IV & $\mathrm{V}$ & VI & VII & VIII & IX & $X$ & XI & XII & & \\
\hline 2015. & 233.2 & 184.8 & 186.7 & 63.8 & 38.9 & 28.7 & 3.6 & 64.7 & 43.6 & 194.7 & 133.3 & 0.0 & 1176.0 & 438.0 \\
\hline 2016. & 240.1 & 273.3 & 316.0 & 82.6 & 268.2 & 158.7 & 78.0 & 3.8 & 84.4 & 223.8 & 264.1 & 0.7 & 1993.7 & 899.5 \\
\hline Average & 236.6 & 229.0 & 251.3 & 73.2 & 153.5 & 93.7 & 40.8 & 34.2 & 64.0 & 209.2 & 198.7 & 0.3 & 1584.8 & 668.5 \\
\hline
\end{tabular}

The percentage of developed shoots as an indicator of yield of the variety, depends on several factors, among which variety has high importance, ecological conditions in the production year, method of pruning, length of pruning of the fertile tree, fertilization and health of vines (Popović, 2007). Based on the data presented in Table 3, the highest percentage of developed shoots $(91.17 \%)$ was recorded on the least loaded vines, that is, in vines on which short pruning was applied. Variant V2 $(88.35 \%)$ had a slightly lower percentage of developed shoots, while the lowest percentage of developed shoots $(85.02 \%)$ was in the variant with the highest load of vines. Žižak had a significantly higher percentage of developed shoots in all tested variants in the first year of research $(89.34 \%)$ compared to 2016 , when it was $86.52 \%$.

The percentage of fertile shoots (Table 3) was also the highest in vines on which 14 and 18 buds were left, respectively, and amounted 84.25 and $84.45 \%$. In the variant in which two canes of 10 buds each and two spurs with two buds each were left, which is the usual pruning of this variety in the experimental field in Lješkopolje, the percentage of fertile shoots was the lowest and amounted $81.95 \%$. Observing the percentage of fertile shoots by years of research, it can be noted that in $2015(85.3 \%)$ was significantly higher compared to the second year of research when it was $81.87 \%$. 
Table 3. Developed and fertile shoots (\%)

\begin{tabular}{|c|c|c|c|c|c|c|}
\hline \multirow{2}{*}{ Variant } & \multicolumn{2}{|l|}{ Developed shoots (\%) } & \multirow{2}{*}{ Average } & \multicolumn{2}{c|}{ Fertile shoots (\%) } & \multirow{2}{*}{ Average } \\
\cline { 2 - 3 } & 2015 & 2016 & & & \\
\cline { 5 - 7 } & 93.75 & 88.60 & 91.17 & 88.20 & 80.30 & 84.25 \\
\hline V1 & 89.30 & 87.40 & 88.35 & 85.70 & 83.20 & 84.45 \\
\hline V2 & 88.10 & 86.30 & 87.20 & 84.70 & 82.70 & 83.70 \\
\hline V3 & 86.24 & 83.80 & 85.02 & 82.60 & 81.30 & 81.95 \\
\hline V4 & 89.34 & 86.52 & 87.93 & 85.30 & 81.87 & 83.58 \\
\hline Average & & & & & \\
\hline
\end{tabular}

Potential fertility rate or the number of flowers per activated bud (Table 4) was highest in variants $\mathrm{V} 2$ and $\mathrm{V} 1$, accounting 1.07 and 1.06, respectively, while in vines with a load of 20 and 24 buds, this coefficient was significantly lower and accounted 0.97 and 0.91 , respectively. The influence of climatic conditions on this fertility indicator was not pronounced in studied years.

Tab.4. Potential, relative and absolute coefficient of yield of Žižak variety

\begin{tabular}{|c|c|c|c|c|c|c|c|c|c|}
\hline Variant & \multicolumn{2}{|c|}{$\begin{array}{c}\text { Average } \\
\text { number of } \\
\text { inflorescences } \\
\text { per bud }\end{array}$} & Average & \multicolumn{2}{|c|}{$\begin{array}{c}\text { Average } \\
\text { number of } \\
\text { inflorescences } \\
\text { per shoot }\end{array}$} & Average & \multicolumn{2}{|c|}{$\begin{array}{c}\text { Average } \\
\text { number of } \\
\text { inflorescences } \\
\text { per fertile shoot }\end{array}$} & \\
\cline { 2 - 6 } & 2015 & 2016 & & 2015 & 2016 & & 2015 & 2016 & \\
\hline V1 & 1.02 & 1.10 & 1.06 & 1.09 & 1.24 & 1.16 & 1.24 & 1.54 & 1.39 \\
\hline V2 & 1.09 & 1.05 & 1.07 & 1.22 & 1.20 & 1.21 & 1.43 & 1.46 & 1.44 \\
\hline V3 & 0.99 & 0.96 & 0.97 & 1.13 & 1.11 & 1.12 & 1.33 & 1.34 & 1.33 \\
\hline V4 & 0.92 & 0.91 & 0.91 & 1.07 & 1.09 & 1.08 & 1.30 & 1.34 & 1.32 \\
\hline Average & 1.00 & 1.00 & 1.00 & 1.12 & 1.16 & 1.14 & 1.32 & 1.42 & 1.37 \\
\hline
\end{tabular}

The relative yield rate had the highest value (1.21) in vines on which 14 buds were left in winter pruning, while the lowest number of flowers per shoot (1.08) was measured in vines loaded with 24 buds. A higher number of flowers per shoot in all tested variants were during the first year of research, which is a consequence of more favourable climatic conditions in this year of research.

The coefficient of fertility was approximately equal in both studied years. As shown in Table 4, variants V2 (1.44) and V1 (1.39) stood out in terms of number of flowers per fertile shoot, while in variants with a load of 20 and 24 buds this yield indicator had significantly lower values - 1.33 and 1.32, respectively. Pejović (1982) stated that with the increase of the vine load with buds, the average number of flowers per bud, per shoot and fertile shoot decreases, which is in accordance with the results of this research. Savić (2003) states that the average number of flowers per bud is $0.97,1.15$ per developed shoot, and 1.38 per fertile shoot which is also in line with results of this study.

The grape yield per unit area, as an absolute indicator of the variety yield, is conditioned by a large number of factors. Among the most important of them 
are the biological characteristics of the variety, production technology and ecological conditions in year of research (Cindrić et al., 2000). From the results shown in Table 5 , it can be noted that the lowest yield of grapes $(2.74 \mathrm{~kg} / \mathrm{vine})$ was measured in the variant V1 (14 buds), while the highest yield was achieved in the variant with the highest load of grape buds $-3.60 \mathrm{~kg} / \mathrm{vine}$. Statistical data processing showed that the yield of grapes in the variant with the lowest load of vines in the two-year average is significantly lower compared to other loads applied. Other differences found in grape yields were without statistical significance. The achieved yields in studied years were at the level stated for Žižak variety by other authors in the same agroecological conditions (Savić, 2003; Maraš et al. 2012; Popović et al. 2017). According to Burić (1995), Žižak is a variety with medium to high yields ranging from 10 to $15 \mathrm{t} / \mathrm{ha}$.

Number of bunches - The number of bunches per vine depends on the method of pruning, ecological growing conditions, but also on the applied agricultural techniques (Cindrić et al., 2000). With the increase of the load with fertile buds, from the variant with load of 14 buds to the variant with 24 buds per vine, the number of harvested bunches significantly increased. The variant with 14 buds (14.86) had the lowest number of bunches per vine in the two-year average, while the variant V4 (22.15) had the highest number of bunches. The 24 - bud variant had significantly very higher number of bunches compared to all other tested variants. A significantly higher number of bunches was also determined by comparing variants V3 (19.55) and V2 (19.30) with variant V1.

Table 5. Bunch weight and grape yield of Žižak variety

\begin{tabular}{|c|c|c|c|c|c|c|c|c|c|}
\hline \multirow{2}{*}{ Variant } & \multicolumn{3}{|c|}{ Number of bunches } & \multicolumn{3}{c|}{ Bunch weight (g) } & \multicolumn{3}{c|}{ Yield ( kg/vine) } \\
\cline { 2 - 11 } & 2015 & 2016 & $\begin{array}{l}2015- \\
2016\end{array}$ & 2015 & 2016 & $\begin{array}{l}2015- \\
2016\end{array}$ & 2015 & 2016 & $\begin{array}{c}2015- \\
2016\end{array}$ \\
\hline V1 & 14.33 & 15.40 & 14.86 & 196 & 174 & 185 & 2.81 & 2.68 & 2.74 \\
\hline V2 & 19.62 & 18.99 & 19.30 & 186 & 169 & 178 & 3.65 & 3.21 & 3.43 \\
\hline V3 & 19.88 & 19.23 & 19.55 & 172 & 170 & 171 & 3.42 & 3.27 & 3.34 \\
\hline V4 & 22.24 & 22.00 & 22.12 & 165 & 159 & 162 & 3.67 & 3.50 & 3.60 \\
\hline Average & 19.00 & 18.90 & 18.95 & 180 & 168 & 174 & 3.38 & 3.16 & 3.27 \\
\hline
\end{tabular}

\begin{tabular}{|l|c|c|c|c|c|c|}
\hline \multirow{2}{*}{ Parameter } & \multicolumn{2}{|c|}{ Number of bunches } & \multicolumn{2}{c|}{ Bunch weight } & \multicolumn{2}{c|}{ Grape yield } \\
\cline { 2 - 7 } & LSD 0.05 & LSD 0.01 & LSD 0.05 & LSD 0.01 & LSD 0.05 & LSD 0.01 \\
\hline $2015-2016$ & 0.622 & 0.875 & 5.650 & 7.982 & 0.399 & 0.562 \\
\hline
\end{tabular}

Bunch weight - The results of the study of the average bunch weight of Žižak variety are shown in Table 5. Analyzing the two-year average values, it can be noted that in vines loaded with 24 buds the bunch weight was the lowest and accounted $162 \mathrm{~g}$, while the highest bunch weight was in vines with 14 buds - 185 g. In variant V1 (14 buds), the average bunch weight was significantly very higher in relation to other loads. Variants V2 -178 $\mathrm{g}$ and V3-171 $\mathrm{g}$ had also a significantly higher bunch weight compared to variant V4. All tested load variants had a higher bunch weight in the first year of the study. The higher 
average bunch weight in the first year of the experiment is a consequence of significantly more favourable environmental conditions in this year, especially concerning temperature. During 2015, the average air temperatures in the vegetation period were significantly higher compared to 2016. The obtained results are in accordance with the results obtained by Popovic et al. in 2013, which state that the bunch weight of the Vranac variety in the Podgorica vineyards area was also higher in climatically more favourable years. The average bunch weight in these studies was at the level of values that are stated by Maraš et al. (2012) and Popović et al. (2017) for variety Žižak in the same agroecological conditions.

Table 6. Sugar and acid content in the must of variety Žižak

\begin{tabular}{|c|c|c|c|c|c|c|}
\hline \multirow{2}{*}{ Variant } & \multicolumn{3}{|c|}{ Sugar content (\%) } & \multicolumn{3}{c|}{ Acid content (g/l) } \\
\cline { 2 - 7 } & 2015 & 2016 & $\begin{array}{c}2015- \\
2016\end{array}$ & 2015 & 2016 & $\begin{array}{c}2015- \\
2016\end{array}$ \\
\hline V1 & 22.42 & 21.73 & 22.00 & 5.95 & 5.80 & 5.87 \\
\hline V2 & 22.63 & 21.97 & 22.32 & 5.70 & 5.60 & 5.65 \\
\hline V3 & 22.13 & 21.33 & 21.70 & 6.20 & 6.00 & 6.10 \\
\hline V4 & 21.77 & 20.99 & 21.35 & 6.35 & 6.20 & 6.27 \\
\hline Average & 22.23 & 21.50 & 21.84 & 6.05 & 5.90 & 5.97 \\
\hline
\end{tabular}

\begin{tabular}{|l|c|c|c|c|}
\hline \multirow{2}{*}{ Parameter } & \multicolumn{2}{|c|}{ Sugar content } & \multicolumn{2}{c|}{ Acid content } \\
\cline { 2 - 5 } & LSD 0.05 & LSD 0.01 & LSD 0.05 & LSD 0.01 \\
\hline $2010-2012$ & 0.471 & 0.664 & - & 0.358 \\
\hline
\end{tabular}

The sugar content in must, apart from the variety, degree of ripeness and health condition of the grapes, climatic conditions in the phase of grape ripening; significantly depends on the production technology (Ranković-Vasić, 2011). Based on the results shown in Table 6 , it can be noted that the highest sugar content in must was measured in the variant V2 (22.32\%), and the lowest in the variant with the highest load of vine with buds (21.35\%). Statistical processing of the data showed that variant V2 has significantly higher sugar content in the must than the variant V4 and a significantly higher content in relation to the variant V1. There is also a significant difference between the 14-bud variant and the 24bud variant. Similar results were obtained by Pejović (1982) and Maraš et al. (2012) who obtained higher sugar content in must in variants with a lower load of vines with fertile buds. The sugar content in must in all tested variants was higher in 2015, which is a direct consequence of the different meteorological conditions that prevailed in this year of the experiment. In 2016, with lower average vegetation air temperature and a higher amount of precipitation in the vegetation period, lower sugar content was found in must. Vukosavljevic et al. came to similar results (2011) who also found a higher sugar content in must in years with higher mean vegetation temperatures. 
The acid content in the must is an important indicator of the quality of grapes, because the taste and harmony of grapes and produced wine depends on their presence (Popović, 2020). The results of two - year study demonstrated that the average acid content in must was satisfactory and characteristic for Žižak variety grown in agroecological conditions of Podgorica vineyard area. The highest content of acids in must was found in variant V4 $(6.27 \mathrm{~g} / \mathrm{l})$, while with the lowest content was measured in variant V2 $(5.65 \mathrm{~g} / \mathrm{l})$. Statistical processing of the data showed that the variant with 24 buds load per vine had a significantly very higher acid content in the must compared to vines loaded with 14 buds $(5.87 \mathrm{~g} / \mathrm{l})$ and 18 buds $-5.65 \mathrm{~g} / \mathrm{l}$.

In vines with a load of 20 buds, the acid content was also significantly higher in relation to the V2 variant. These results are in line with the results of Popović et al. (2017), Maraš et al. (2012), Savić (2003), while Burić (1995) states higher values for the acid content in the must of Žižak (6-9 g/l), which is probably a consequence of different agroecological conditions in which their research was conducted.

\section{CONCLUSIONS}

Based on the conducted research, it can be concluded:

-The percentage of total and fertile shoots during the two-year study was highest in vines that were loaded with 14 buds, that is, in vines on which short pruning was applied, while the lowest percentage of total and fertile shoots in both examined years was the variant with the highest load of vines with fertile buds.

-The potential fertility rate was approximately the same in examined years. The highest number of inflorescences per bud had a variant with 18 buds-1.07, while the variant with the lowest fertility rate $(0.91)$ had a variant with 24 buds. The average number of inflorescences per shoot and fertile shoot was also higher in variants with a lower load of vine. According to the number of inflorescences per fertile shoot (1.44), variant V2 stood out, in which 2 canes with seven buds and two spurs with two buds were left by pruning.

-The average grape yield in the two-year period was the highest in vines loaded with 24 buds, while the lowest yield was measured in vines loaded with 14 buds.

- The number of bunches varied significantly between the tested variants and ranged from 14.86 in variant V1 to 22.12 in variant V4.

-The average weight of bunches varied from 162 to $185 \mathrm{~g}$. The highest weight of bunches had vines loaded with the lowest number of buds, that is, vines where short pruning was applied.

- The average sugar content in the must in the two-year period was the highest in the 18 buds variant. The higher sugar content in all tested variants was in 2015, which is a consequence of higher average air temperatures in the grapevine vegetation period. 
-The acid content in must was characteristic of tested variety in Podgorica vineyard area. The highest acid content $(6.27 \mathrm{~g} / \mathrm{l})$ was found in the variant with the highest load of vines.

\section{REFERENCES}

Burić, D. (1995): Savremeno vinogradarstvo, Nolit, Beograd.

Cindrić, P., Korać, N., Kovač, V. (2000): Sorte vinove loze, Poljoprivredni fakultet Novi Sad.

Mijatović, D., Jovanović-Cvetković, T. (2018): Zimska rezidba vinove loze, Banja Luka

Maraš, V, Košmerl, T.,Kodžulović, V., Šućur, S., Savović, A., Perišić, M. (2012): Yield and oenological potential of Montenegrin autochthonous grape varieties 'Kratošija' and 'Žižak', Journal of Hygienic Engineering and Design, 158-162

Maraš, V, Popović, T., Gazivoda, A., Raičević, J., Kodžulović, V., Mugoša, M., Sućur, S. (2015): Origin and characterization of Montenegrin grapevine varieties, Vitis 54, 135-137

Miroševic, N, Karoglan-Kontić, J. (2008): Vinogradarstvo, Agronomski fakultet, Zagreb.

Pejović Lj. (1982): Uticaj opterećenosti čokota rodnim okcima i načina održavanja zemljišta $u$ vinogradu na neke biološke i tehnološke karakteristike sorte vranac u uslovima navodnjavanja, Doktorska disertacija, Novi Sad.

Pejović, Lj., Ulićević, M. (1992): Rezultati proučavanja nekih bijelih vinskih sorata vinove loze u okolini Titograda, Poljoprivreda i šumarstvo, Titograd.

Popović, T. (2007): Uticaj đubrenja i navodnjavanja na biološke i tehnološke osobine vinove loze sorte vranac. Doktorska disertacija. Univerzitet u Novom Sadu. Poljoprivredni fakultet.

Popović, T., Mijović, S., Pajović, R. (2013): The influence of climatic factors on the level and quality of yield of Vranac variety in Podgorica vineyards. Agriculture and forestry, Vol. 59. Issue 2: 137-145, 2013, Podgorica.

Popović, T., Kalač, A., Raičević, D., Pajović, R. (2017): Rodnost i kvalitet grožđa sorte Žižak u podgoričkom vinogorju. XXII Savetovanje o biotehnologiji, Zbornik radova 1: 231-237, Čačak, Srbija.

Popović, T., Mijović, S., Pajović-Šćepanović, R., Raičević, D. (2020): Analysis of possibilities of reducing the quantity of mineral fertilizer application using different types of organic fertilizers in Cardinal grape variety, Agriculture and forestry, Vol. 66 Issue 1: 261-268, Podgorica

Ranković-Vasić, Z., Atanacković, Z., Vujadinović, M., Vuković, A., Sivčev, B. (2011): Uticaj klimatskih faktora na kvalitet grožđa sorte Burgundac crni u vršačkom vinogorju, International Scientific Symposium of Agriculture "Agrosym Jahorina 2011", Zbornik radova, str. 177-183, Jahorina.

Vujović, D. (2013): Vinogradarstvo, Poljoprivredni fakultet Univerziteta u Beogradu, Beograd - Zemun 
Vukosavljević, V., Boškov, K., Pajović, R., Stojanov, M., Đurić, M., Murtić, S., Kojović, R. (2011): Rodni potencijal i kvalitet sorte Merlo u trsteničkom vinogorju. XVI Savetovanje o Biotehnologiji sa međunarodnim učešćem, Zbornik radova, Vol. 16 (18): 385-390. Mart 2011, Čačak, Srbija.

Savić, S. (2003): Ekološki uslovi i autohtone sorte vinove loze u Crnoj Gori, Podgorica

Sefo, S., Hadžić, S., Kraljević, M., Delić, M. (2020): Uticaj različitog opterećenja čokota rodnim pupoljcima na rodnost sorte Trnjak. XXV savetovanje o biotehnologiji, Zbornik radova 1: 179-184, Čačak, Srbija. 